\title{
Communication \\ Direct Electrochemical Reduction of Bicarbonate to Formate Using Tin Catalyst
}

\author{
Andreu Bonet Navarro ${ }^{1,2, *}$, Adrianna Nogalska ${ }^{2}$ and Ricard Garcia-Valls ${ }^{1,2}$ \\ 1 Eurecat, Centre Tecnològic de Catalunya, C/Marcel-lí Domingo, 43007 Tarragona, Spain; \\ ricard.garcia@ce.eurecat.org \\ 2 Department of Chemical Engineering, Universitat Rovira I Virgili, Av. Països Catalans, 26, \\ 43007 Tarragona, Spain; adrianna.nogalska@eurecat.org \\ * Correspondence: andreu.bonet@eurecat.org; Tel.: +34-977-297-930
}

check for

updates

Citation: Bonet Navarro, A.;

Nogalska, A.; Garcia-Valls, R. Direct

Electrochemical Reduction of

Bicarbonate to Formate Using Tin

Catalyst. Electrochem 2021, 2, 64-70.

https: / / doi.org/10.3390/

electrochem 2010006

Received: 9 December 2020

Accepted: 5 February 2021

Published: 10 February 2021

Publisher's Note: MDPI stays neutral with regard to jurisdictional claims in published maps and institutional affiliations.

Copyright: (C) 2021 by the authors Licensee MDPI, Basel, Switzerland. This article is an open access article distributed under the terms and conditions of the Creative Commons Attribution (CC BY) license (https:// creativecommons.org/licenses/by/ $4.0 /)$

\begin{abstract}
Nowadays, the self-accelerating increase in global temperatures strengthens the idea that the cutting of $\mathrm{CO}_{2}$ emissions will not be enough to avoid climate change, thus $\mathrm{CO}_{2}$ from the atmosphere must be removed. This gas can be easily trapped by converting it to bicarbonate using hydroxide solutions. However, bicarbonate must be converted into a more valuable product to make this technology profitable. Several studies show great efficiency when reducing bicarbonate solutions saturated with pure $\mathrm{CO}_{2}$ gas to formate. However, those approaches don't have a real application and our objective was to obtain similar results without pure $\mathrm{CO}_{2}$ saturation. The method consists of electroreduction of the bicarbonate solution using bulk tin ( $\mathrm{Sn}$ ) as catalysts. Tin is a relatively cheap material that, according to previous studies performed in saturated bicarbonate solutions, shows a great selectivity towards formate. The ${ }^{1} \mathrm{H}$ NMR analysis of bicarbonate solutions after electroreduction show that, without pure $\mathrm{CO}_{2}$ gas, the faradic efficiency is around $18 \%$ but almost $50 \%$ for saturated ones. The formate obtained could be used to power formate/formic acid fuel cells obtaining a battery-like system, with greater energy density than common lithium batteries, but electroreduction efficiency needs to be improved to make them competitive.
\end{abstract}

Keywords: bicarbonate electroreduction; bulk tin catalyst; formate production; atmospheric $\mathrm{CO}_{2}$ electroreduction

\section{Introduction}

Since the start of the industrial revolution, the atmospheric $\mathrm{CO}_{2}$ levels increased drastically and exceeded the 400 ppm in 2016 [1]. For this reason, some studies indicate that just cutting off or reducing the $\mathrm{CO}_{2}$ emissions will not be enough to avoid or mitigate the effects of climate change, and $\mathrm{CO}_{2}$ removal from the atmosphere is going to be necessary [2] One way to absorb atmospheric $\mathrm{CO}_{2}$ is by transforming it into bicarbonate using hydroxide solutions, like the system developed by A. Nogalska and R. Garcia [3]. Bicarbonate is a product with low value and not many applications, but its conversion to more useful and valuable hydrocarbons is becoming an economically viable way to reuse it [4].

Many different direct $\mathrm{CO}_{2}$ electroreduction techniques use bicarbonate solutions previously saturated with pure $\mathrm{CO}_{2}$ gas to obtain hydrocarbons or alcohols showing significant selectivity. The main inconvenience of these techniques are its practical applications because $\mathrm{CO}_{2}$ is present in the atmosphere at very low concentrations, and it is almost impossible to saturate a bicarbonate solution with $\mathrm{CO}_{2}$ using atmospheric air, with just a few studies performing it on non- $\mathrm{CO}_{2}$ saturated bicarbonate solutions [5-11]. Theoretically, direct $\mathrm{CO}_{2}$ electroreduction is performed by $\mathrm{CO}_{2}$ activation on a catalyst surface and its following reaction with two protons $\left(2 \mathrm{H}^{+}\right)$. Generally, the bicarbonate acts as an electrolyte, favoring the $\mathrm{CO}_{2}$ dissolution and increasing the conductivity of the aqueous solution, but, since dissolved bicarbonate is always in equilibrium with dissolved $\mathrm{CO}_{2}$, it is still not clear if the carbon source is bicarbonate or $\mathrm{CO}_{2}[12-16]$. 
The electrochemical reduction of $\mathrm{CO}_{2}$ into formate performed with water as a proton source is a very attractive technology, due to the great energy density of formate that can be used to power formate fuel cells [17-19], as a future alternative to lithium batteries [20,21]. In addition, this liquid fuel may be easily stored and transported using existing infrastructures. This way, renewable energy, which is intermittent, unpredictable, and with irregular production peaks, could be stored as formate and released during low production periods without any additional emissions of $\mathrm{CO}_{2}$ into the atmosphere.

Our goal is to study the viability of reducing a non- $\mathrm{CO}_{2}$ saturated bicarbonate solution into formate using a bulk tin catalyst, which is a relatively cheap material, simple to use and with great selectivity towards formate in mild conditions [22-26]. For this purpose, electrochemical studies were performed with the use of potassium bicarbonate. Moreover, the influence of $\mathrm{CO}_{2}$ saturation on faradic efficiency of conversion was evaluated.

\section{Materials and Methods}

\subsection{Materials}

Tin foil ( $99.8 \%$ trace metals basis), $0.25 \mathrm{~mm}$ thick, provided by Alfa Aesar (Haverhill, MA, USA), was used as a working electrode and highly pure $\mathrm{KHCO}_{3}$ (Bio Ultra $99.5 \%$ ), supplied by Sigma-Aldrich (St. Louis, MO, USA), with a content of iron lower than $5 \mathrm{mg} / \mathrm{Kg}$ was used for preparation of the electrolyte. Milli-Q water was used to prepare solutions. Proton exchange membrane was Nafion ${ }^{\circledR} 117$ membrane (Sigma-Aldrich). Hydrogen peroxide $30 \%$ (v/v) (Sigma-Aldrich) and $95-97 \% \mathrm{H}_{2} \mathrm{SO}_{4}$ (Serviquimia) were used to prepare cleaning solutions for Nafion membrane. To prepare a standard for ${ }^{1} \mathrm{H}$ NMR analysis, 99.8\% $\mathrm{D}_{2} \mathrm{O}$ from Panreac and 99.7\% DMSO (Chromasolv Plus) from Sigma Aldrich were used. $\mathrm{CO}_{2}$ gas used for the electrolyte saturation was pure liquid carbon dioxide $\left(\mathrm{CO}_{2}\right.$ Premier X10) purchased from Carburos Metálicos.

\subsection{Linear Sweep Voltammetry}

Linear sweep voltammetry (LSV) was performed prior to electroreduction experiments to evaluate which is the lowest potential that is high enough to allow significant product formation, without experimenting excessive $\mathrm{H}_{2}$ gas formation at high potentials. To study the effects of $\mathrm{KHCO}_{3}$ concentration, three solutions with different concentrations $(0.1,0.5$, and $1.5 \mathrm{M}$ ) were prepared. Finally, the $1.5 \mathrm{M} \mathrm{KHCO}_{3}$ solution was submitted to saturation with $\mathrm{CO}_{2}$ gas during $30 \mathrm{~min}$ at a flow rate of $14.47 \mathrm{sccm}$ to test its effects. Constant stirring was applied to ensure homogeneous solution, improve bicarbonate migration to the electrode, and facilitate the release of residual gas bubbles formed during reaction.

All experiments were carried out in a gas-tight Teflon H-cell (Figure 1 and Figure S1), equipped with the standard three-electrode system. The counter electrode was a bulk Platinum (Pt) foil of $1 \mathrm{~cm}^{2}$, the reference electrode was an $\mathrm{Ag} / \mathrm{AgCl} / 3 \mathrm{M} \mathrm{KCl}(0.21 \mathrm{~V})$, and the working electrode consisted of a tin (Sn) foil of $5 \mathrm{~cm}^{2}$. A Nafion membrane was used to separate the working and counter electrode compartments ( $25 \mathrm{~mL}$ each) to prevent oxidation of the reduced products. The membrane was washed by immersion in an $80{ }^{\circ} \mathrm{C}$ aqueous solution, for $1 \mathrm{~h}$ each, in the following order: $0.5 \mathrm{M} \mathrm{H}_{2} \mathrm{SO}_{4}, \mathrm{H}_{2} \mathrm{O}_{2} 3 \%$, and distilled water to eliminate possible contamination (Figure S2). The working electrode was not pretreated before experiments, as the native $\mathrm{SnO}_{2}$ layer is reported to increase the catalytic activity [27], and the whole system was leaned with distilled water between each experiment. An AutoLab PGSTAT 302N potentiostat (Metrohm, Autolab B.V.) was used in all the electrochemical experiments. All the LSV were conducted at a scan rate of $100 \mathrm{mV} / \mathrm{s}$ in a range of potentials between 0 and $-2.0 \mathrm{~V}$ in the presence of the reference electrode. 


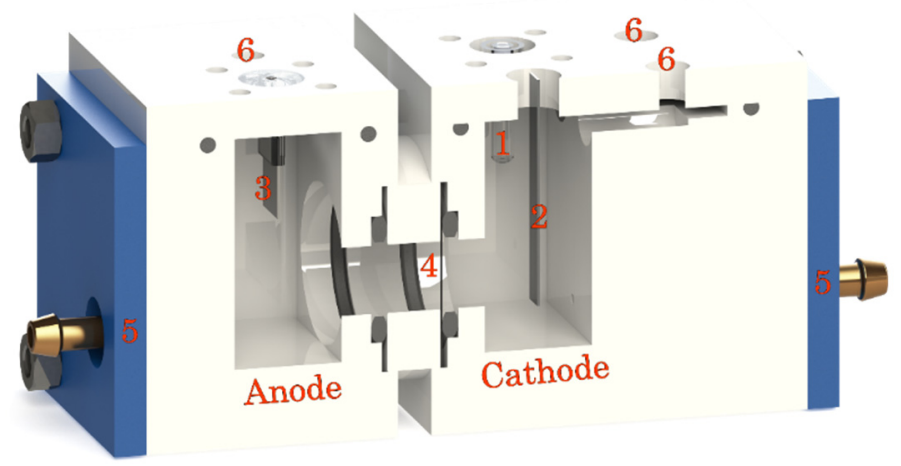

Figure 1. Cross section of Teflon H-cell used for the experiments. The cell consists of two compartments (Anodic and Cathodic) filled with the bicarbonate solution and separated by a proton exchange membrane (4) to prevent re-oxidation of reduced products on the anode. The cathodic compartment contains the working electrode (2), where the $\mathrm{CO}_{2}$ is reduced and the reference electrode (1) $(\mathrm{Ag} / \mathrm{AgCl}(0.21 \mathrm{~V})$ is used to maintain a stable potential reading. In the anodic compartment, there is the counter electrode (3) (Pt foil) where water splitting takes place. For the saturation of solution with $\mathrm{CO}_{2}$, two inlets (5) and outlets (6) for gas were used.

\subsection{Electroreduction Experiments}

The electroreduction experiments were carried out in potentiostatic conditions for $1.5 \mathrm{~h}$ in the same Teflon $\mathrm{H}$-cell used for LSV analysis. In addition, constant stirring, $\mathrm{CO}_{2}$ presaturation, and membrane-system cleaning were performed as described in the previous section and for the same purposes. The electroreduction potential was chosen based on the LSV analysis and set to $-1.6 \mathrm{~V}$. Beyond that, a significant increase of reduction current and gas bubble formation associated with $\mathrm{CO}(2)$ and $\mathrm{H}_{2}$ (3) formation can be observed [28]. Some of those bubbles stayed in the working electrode surface, diminishing its active area, and reducing the efficiency of the reaction. The materials and the samples used are the same described in the voltammetry section.

The most probable electroreduction reaction of bicarbonate to formate in these conditions is showed (1), but formate formation from dissolved $\mathrm{CO}_{2}$ is also possible [12-16]:

$$
\mathrm{HCO}_{3}-(\mathrm{aq})+2 \mathrm{H}^{+}(\mathrm{aq})+2 \mathrm{e}-\rightarrow \mathrm{HCO}_{2}-(\mathrm{aq})+\mathrm{H}_{2} \mathrm{O}
$$

The most likely side reactions of $\mathrm{CO}$ and $\mathrm{H}_{2}$ formation are:

$$
\begin{gathered}
2 \mathrm{CO}_{2}(\mathrm{aq}) \rightarrow 2 \mathrm{CO}(\mathrm{g})+\mathrm{O}_{2}(\mathrm{~g}) \\
2 \mathrm{H}^{+}+2 \mathrm{e}-\rightarrow \mathrm{H}_{2}(\mathrm{~g})
\end{gathered}
$$

\subsection{Product Analysis}

The analysis of the reaction's products was performed by $1 \mathrm{H}$ NMR (VARIAN Mercury VX400). DMSO 0.010M in $\mathrm{D}_{2} \mathrm{O}$ was used as an internal standard for quantification of the obtained products. Catholyte samples of $600 \mu \mathrm{L}$ were mixed with $100 \mu \mathrm{L}$ of standard. To obtain the peaks coming from products, we suppressed the water peak by irradiation.

Based on the determination of formate concentration though the NMR analysis with Mestrenova, Faradic efficiency FE (\%) was calculated considering passed charge and electrons transferred with the following Equation (4):

$$
\mathrm{FE}(\%)=\mathrm{q}_{\exp } / \mathrm{q}_{\text {theo }} \times 100
$$

Experimentally used charge $[C] q_{\exp }(5)$ is calculated by:

$$
\mathrm{q}_{\exp }=F n z
$$


$F$ stays for Faraday constant $9.6485 \times 10^{4}[\mathrm{C} / \mathrm{mol}], n$ is the amount of formate moles obtained by proton NMR, and $z$ are electrons needed for bicarbonate conversion to formate based on chemical reaction $(2 \mathrm{e}-)$.

In addition, theoretical charge $\mathrm{q}_{\text {theo }}(6)[\mathrm{C}]$ passed charge is obtained chronoamperograms by:

$$
\mathrm{Q}_{\mathrm{exp}}=-I t
$$

where $I$ is the total current $[\mathrm{A}]$ and $t$ is the reaction time [s].

\section{Results and Discussion}

\subsection{Linear Sweep Voltammetry (LSV)}

The LSV measurements show a small peak between $-0.9 \mathrm{~V}$ to $-1.0 \mathrm{~V}$ corresponding to reduction of the small $\mathrm{SnO}_{2}$ layer usually present on bulk Sn [21] (Figure 2). At potentials below $-1.2 \mathrm{~V}$, current density increases exponentially in all cases, probably associated with bicarbonate and hydrogen electroreduction. In addition, as current density increases, $\mathrm{CO}_{2}$ bubbling on working electrode ( $\mathrm{Sn}$ foil) is observed, probably associated with $\mathrm{H}_{2}$ or $\mathrm{CO}$ and other residual gasses [29]. Furthermore, oxygen bubbles are observed on the platinum counter electrode. Current density is higher when $\mathrm{CO}_{2}$ presaturation is used (Figure 2b), and the product analysis will determine if this is associated with more bicarbonate electroreduction or not.

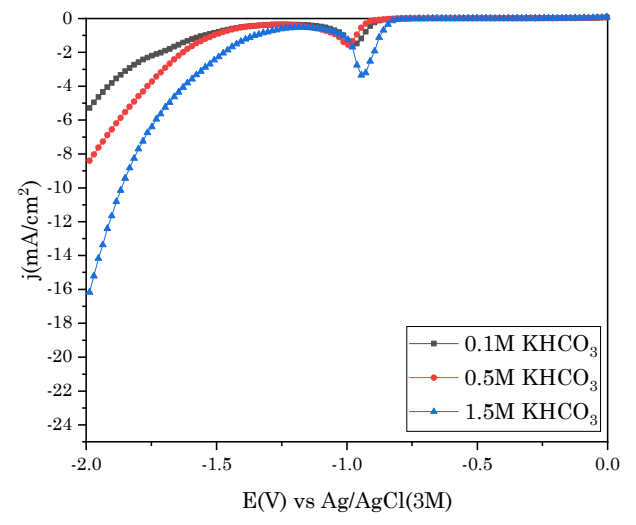

(a)

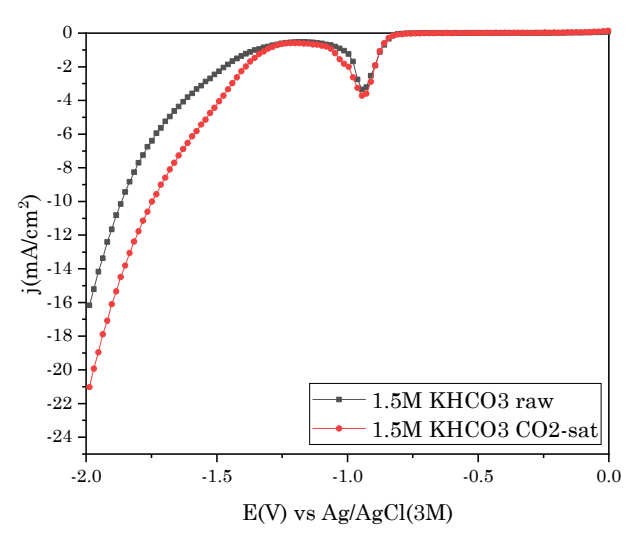

(b)

Figure 2. (a) LSV) at different potassium bicarbonate $\left(\mathrm{KHCO}_{3}\right)$ concentrations of non- $\mathrm{CO}_{2}$ saturated solutions; (b) comparison of a linear sweep voltammetry (LSV) between saturated with $\mathrm{CO}_{2}$ and non-saturated potassium bicarbonate $\left(\mathrm{KHCO}_{3}\right)$ aqueous solutions.

\subsection{Chronoamperometry}

The working potential for electroreduction experiments was set at $-1.6 \mathrm{~V}$ in order to obtain the greatest energy density without observing excessive formation of residual non-desired gasses (chronoamperograms shown in Figure 3). The current density should increase while augmenting $\mathrm{KHCO}_{3}$ concentration, due to the improved conductivity of the solution and increased reaction rates. As expected, the results confirm an energy density six times higher for $1.5 \mathrm{M} \mathrm{KHCO}_{3}$ solution respectively compared with $0.1 \mathrm{M} \mathrm{KHCO}_{3}$ solution at $-1.6 \mathrm{~V}$ (Figure 3a). For the $\mathrm{CO}_{2}$ saturated experiments, the same trend is observed with a $33 \%$ increase on the current density at $-1.6 \mathrm{~V}$ for the saturated solution (Figure $3 \mathrm{~b}$ ). The electroreduction current is stable during this interval of time for all experiments, slightly decreasing over time for experiments performed at $1.5 \mathrm{M} \mathrm{KHCO}_{3}$, which could be due to faster exhaustion of reactants, membrane poisoning, or catalyst degradation or even a reduction of solution volume. A small amount of noise most commonly present in experiments at higher currents are due to gas bubbles formation, which attach and detach from the catalyst surface affecting the active area. 


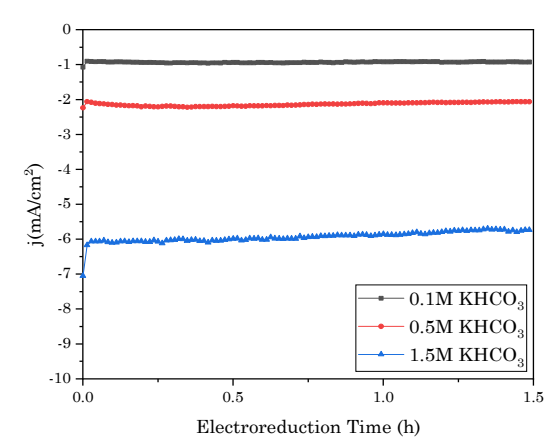

(a)

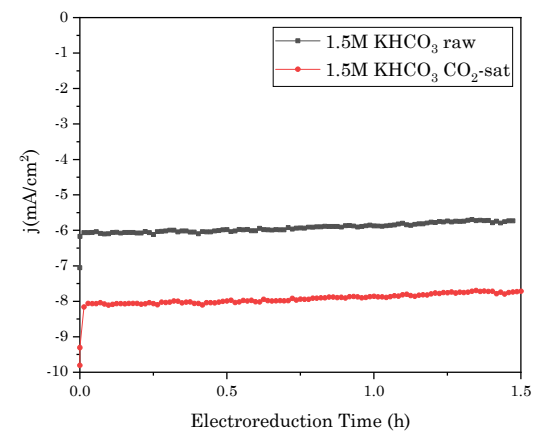

(b)

Figure 3. (a) Chronoamperogram at $-1.6 \mathrm{~V}$ of different potassium bicarbonate $\left(\mathrm{KHCO}_{3}\right)$ concentrations of non- $\mathrm{CO}_{2}$ saturated solutions; (b) chronoamperogram at $-1.6 \mathrm{~V}$ of $\mathrm{CO}_{2}$ saturated and non-saturated bicarbonate solution.

\subsection{Analysis and Quantification of Products by ${ }^{1} H$ NMR}

The ${ }^{1} \mathrm{H}$ NMR spectra show three singlets at around 8.24, 4.63 and $2.50 \mathrm{ppm}$ corresponding to $\mathrm{HCOOK}, \mathrm{DMSO}$, and $\mathrm{H}_{2} \mathrm{O}$, respectively (Figure S3). The slightly basic media $(\sim \mathrm{pH} 9)$ of the potassium bicarbonate solution, including the non-observation of an $\mathrm{O}-\mathrm{H}$ bond of formic acid around $11 \mathrm{ppm}$, confirm that potassium formate (HCOOK) is the main product, and the acid form is not present for reaction conditions. The observation of only one product in the liquid phase indicates a high selectivity of tin foil towards formate production.

The faradaic efficiency towards formate shows a significative increase from $0 \%$ to $18 \%$ in $0.1 \mathrm{M}$ and $1.5 \mathrm{M}$ solutions as summarized in Table 1 . With the saturation of $\mathrm{CO}_{2}$, the efficiency increases from $18 \%$ to $47 \%$, noting the importance of pre-saturating the solution with pure $\mathrm{CO}_{2}$.

Table 1. Summary of the effects of the potassium bicarbonate $\left(\mathrm{KHCO}_{3}\right)$ concentration and the $\mathrm{CO}_{2}$ pre-saturation on the faradaic efficiency of the electroreduction to formate.

\begin{tabular}{cccccc}
\hline KHCO3 (aq) Concentration (M) & $\mathbf{0 . 1} \mathbf{M}$ & $\mathbf{0 . 5} \mathbf{M}$ & $\mathbf{1 . 5} \mathbf{M}$ & No & Y.5 \\
\hline $\mathrm{CO}_{2}$ pre-saturation & No & No & 18 & 47 \\
\hline Faradaic efficiency (\%) & n.d. & 8 & & 18 \\
\hline
\end{tabular}

As we can see in Table 2, bulk Sn seems to have the highest efficiency compared with other similar bulk catalysts working in similar conditions.

Table 2. Summary of $\mathrm{CO}_{2}$ electroreduction efficiencies towards $\mathrm{HCOOH} / \mathrm{HCOOK}$ of similar bulk catalysts.

\begin{tabular}{|c|c|c|c|c|c|}
\hline Electrode & Reference Electrode & Electrolyte & $\mathrm{CO}_{2}$ Saturation & $\begin{array}{c}\text { Faradaic Efficiency (\%) } \\
\text { towards HCOOK/HCOOH }\end{array}$ & Ref. \\
\hline Ag (99.98\%) electrode & \multirow[b]{2}{*}{$\begin{array}{l}-1.6 \mathrm{~V} \text { vs. } \mathrm{Ag} / \mathrm{AgCl} \\
\text { saturated with } \mathrm{KCl}\end{array}$} & \multirow{2}{*}{$\begin{array}{c}0.1 \mathrm{M} \mathrm{KHCO} \\
\text { aqueous solution }\end{array}$} & \multirow[b]{2}{*}{ No } & $n$ & \multirow[b]{2}{*}{ [30] } \\
\hline $\begin{array}{l}\text { Au }(99.95 \%) \\
\text { electrode }\end{array}$ & & & & 6 & \\
\hline Pd Metal & $1.8 \mathrm{~V}$ vs. $\mathrm{Ag} / \mathrm{AgCl}$ & $\begin{array}{c}0.1 \mathrm{M} \mathrm{KHCO}_{3} \\
\text { aqueous solution }\end{array}$ & No & 4.4 & [31] \\
\hline $\mathrm{Cu}$-Based catalysts & $\mathrm{Ag} / \mathrm{Ag}+$ with $0.01 \mathrm{M}$ & $\begin{array}{c}0.5 \mathrm{M} \mathrm{KHCO}_{3} \\
\text { aqueous solution }\end{array}$ & Yes & $3-15$ & [32] \\
\hline
\end{tabular}




\section{Conclusions}

During this brief study, we confirmed the possibility to reduce bicarbonate solutions to formate without using pure $\mathrm{CO}_{2}$, with significant amounts for non- $\mathrm{CO}_{2}$ saturated solutions $(18 \%)$ and almost $50 \%$ for saturated ones.

Bicarbonate can be easily obtained from atmospheric air by $\mathrm{CO}_{2}$ capture, and there is an unlimited stock of it. In addition, $\mathrm{CO}_{2}$ pollutes the atmosphere and increases the greenhouse effect, with serious consequences for our planet and society, so pulling it out of the atmosphere will contribute to mitigate its negative consequences. The direct conversion of atmospheric $\mathrm{CO}_{2}$ stored as bicarbonate will make this technology more competitive in the market, and to have an alternative for formic acid/formate production which is nowadays obtained by a non-renewable and very contaminating process. Another great application of formic acid is fuel cells because they have higher energy density than lithium batteries and they are safer than hydrogen fuels cells. Then, the possibility to have more competitive fuel cells with much higher energy density than current lithium batteries will also increase the competitiveness of renewable energies allowing the possibility to store more energy during its normally irregular energy production peaks.

To conclude, we can affirm that increasing the electroreduction efficiency and selectivity of bicarbonate to formate will become a great advance in energy storage systems, thus making renewable energies even more competitive, then investing in this technologies is a great way to fight climate change and take economical profit at the same time.

Supplementary Materials: The following are available online at https:/ /www.mdpi.com/2673-329 3/2/1/6/s1, Table S1: List of abbreviations, Figure S1: 3D rendered design of Teflon H-cell used for the experiments, Figure S2: Nafion membrane cleaning procedure, Figure S3: 1H NMR spectra of products after electroreduction.

Author Contributions: Conceptualization, R.G.-V.; methodology, A.B.N. and A.N.; investigation, A.B.N. and A.N.; writing-original draft preparation, A.B.N. and A.N.; writing-review and editing, A.N. and R.G.-V.; visualization, A.B.N.; supervision, R.G.-V. All authors have read and agreed to the published version of the manuscript.

Funding: This research was funded by Regional Agency for the Business Competitiveness of the Generalitat de Catalunya (EURECAT-ACCIÓ). Moreover, the Vincente Lopez scholarship from EURECAT was provided for Andreu Bonet Navarro pre-doctoral studies and Ministerio de Economía y Competitividad (ENE2017-86711-C3-3-R).

Institutional Review Board Statement: Not applicable.

Informed Consent Statement: "Not applicable" for studies not involving humans.

Data Availability Statement: Data is contained within the article or supplementary material.

Acknowledgments: The authors would like to acknowledge Ramon Guerrero Grueso for technical support with ${ }^{1} \mathrm{H}-\mathrm{NMR}$ analysis.

Conflicts of Interest: The authors declare no conflict of interest.

\section{References}

1. Smith, M.R.; Myers, S.S. Impact of Anthropogenic $\mathrm{CO}_{2}$ Emissions on Global Human Nutrition. Nat. Clim. Chang. 2018, 8, 834-839. [CrossRef]

2. Workman, M.; McGlashan, N.; Chalmers, H.; Shah, N. An Assessment of Options for $\mathrm{CO}_{2}$ Removal from the Atmosphere. Energy Procedia 2011, 4, 2877-2884. [CrossRef]

3. Nogalska, A.; Zukowska, A.; Garcia-Valls, R. Atmospheric $\mathrm{CO}_{2}$ Capture for the Artificial Photosynthetic System. Sci. Total Environ. 2018, 621, 186-192. [CrossRef]

4. Nitopi, S.; Bertheussen, E.; Scott, S.B.; Liu, X.; Engstfeld, A.K.; Horch, S.; Seger, B.; Stephens, I.E.L.; Chan, K.; Hahn, C.; et al. Progress and Perspectives of Electrochemical $\mathrm{CO}_{2}$ Reduction on Copper in Aqueous Electrolyte. Chem. Rev. 2019, 119, 7610-7672. [CrossRef] [PubMed]

5. Hosseini, S.; Kheawhom, S.; Soltani, S.M.; Aroua, M.K. Electrochemical Reduction of Bicarbonate on Carbon Nanotube-Supported Silver Oxide: An Electrochemical Impedance Spectroscopy Study. J. Environ. Chem. Eng. 2018, 6, 1033-1043. [CrossRef] 
6. Spichiger-Ulmann, M.; Augustynski, J. Electrochemical Reduction of Bicarbonate Ions at a Bright Palladium Cathode. J. Chem. Soc. Faraday Trans. 1 Phys. Chem. Condens. Phases 1985, 81, 713-716. [CrossRef]

7. Li, T.; Lees, E.W.; Goldman, M.; Salvatore, D.A.; Weekes, D.M.; Berlinguette, C.P. Electrolytic Conversion of Bicarbonate into CO in a Flow Cell. Joule 2019, 3, 1487-1497. [CrossRef]

8. Min, X.; Kanan, M.W. Pd-Catalyzed Electrohydrogenation of Carbon Dioxide to Formate: High Mass Activity at Low Overpotential and Identification of the Deactivation Pathway. J. Am. Chem. Soc. 2015, 137, 4701-4708. [CrossRef] [PubMed]

9. Zhong, H.; Fujii, K.; Nakano, Y.; Jin, F. Effect of $\mathrm{CO}_{2}$ Bubbling into Aqueous Solutions Used for Electrochemical Reduction of $\mathrm{CO}_{2}$ for Energy Conversion and Storage. J. Phys. Chem. C 2014, 119, 55-61. [CrossRef]

10. Kortlever, R.; Tan, K.H.; Kwon, Y.; Koper, M.T.M. Electrochemical Carbon Dioxide and Bicarbonate Reduction on Copper in Weakly Alkaline Media. J. Solid State Electrochem. 2013, 17, 1843-1849. [CrossRef]

11. Hori, Y. Electrolytic Reduction of Bicarbonate Ion at a Mercury Electrode. J. Electrochem. Soc. 1983, 130, 2387-2390. [CrossRef]

12. Sreekanth, N.; Phani, K.L. Selective Reduction of $\mathrm{CO}_{2}$ to Formate through Bicarbonate Reduction on Metal Electrodes: New Insights Gained from SG/TC Mode of SECM. Chem. Commun. 2014, 50, 11143-11146. [CrossRef] [PubMed]

13. Ting, L.R.L.; Yeo, B.S. Recent Advances in Understanding Mechanisms for the Electrochemical Reduction of Carbon Dioxide. Curr. Opin. Electrochem. 2018, 8, 126-134. [CrossRef]

14. Isa, P.; Louis, H.; Adesina, K.; Akpan, E. Review article Understanding the Mechanism of Electrochemical Reduction of $\mathrm{CO}_{2}$ Using Cu/Cu-Based Electrodes. Asian J. Nano Mater. 2018, 1, 183-224.

15. Garza, A.J.; Bell, A.T.; Gordon, M.H. Mechanism of $\mathrm{CO}_{2}$ Reduction at Copper Surfaces: Pathways to $\mathrm{C}_{2}$ Products. ACS Catal. 2018, 8, 1490-1499. [CrossRef]

16. Hussain, J.; Skúlason, E.; Jónsson, H. Computational Study of Electrochemical $\mathrm{CO}_{2}$ Reduction at Transition Metal Electrodes. Procedia Comput. Sci. 2015, 51, 1865-1871. [CrossRef]

17. Aslam, N.; Masdar, M.; Kamarudin, S.; Daud, W.R.W. Overview on Direct Formic Acid Fuel Cells (DFAFCs) as an Energy Sources. APCBEE Procedia 2012, 3, 33-39. [CrossRef]

18. Rees, N.V.; Compton, R.G. Sustainable Energy: A Review of Formic Acid Electrochemical Fuel Cells. J. Solid State Electrochem. 2011, 15, 2095-2100. [CrossRef]

19. Nogalska, A.; Navarro, A.B.; Garcia-Valls, R. MEA Preparation for Direct Formate/Formic Acid Fuel Cell—Comparison of Palladium Black and Palladium Supported on Activated Carbon Performance on Power Generation in Passive Fuel Cell. Membranes 2020, 10, 355. [CrossRef] [PubMed]

20. Sharaf, O.Z.; Orhan, M.F. An Overview of Fuel Cell Technology: Fundamentals and Applications. Renew. Sustain. Energy Rev. 2014, 32, 810-853. [CrossRef]

21. Mohapatra, A.; Tripathy, S. A Critical Review of the use of Fuel Cells Towards Sustainable Management of Resources. In IOP Conference Series: Materials Science and Engineering, Proceedings of the International Conference on Mechanical, Materials and Renewable Energy, Sikkim, India, 8-10 December 2017; IOP Publishing: Bristol, UK, 2018; Volume 377, p. 012135. [CrossRef]

22. Prakash, G.K.S.; Viva, F.A.; Olah, G.A. Electrochemical Reduction of $\mathrm{CO}_{2}$ over Sn-Nafion ${ }^{\circledR}$ Coated Electrode for a Fuel-Cell-like Device. J. Power Sources 2013, 223, 68-73. [CrossRef]

23. Cui, C.; Wang, H.; Zhu, X.; Han, J.; Ge, Q. A DFT Study of $\mathrm{CO}_{2}$ Electrochemical Reduction on Pb(211) and Sn(112). Sci. China Chem. 2015, 58, 607-613. [CrossRef]

24. Bumroongsakulsawat, P.; Kelsall, G. Effect of Solution pH on CO: Formate Formation Rates during Electrochemical Reduction of Aqueous $\mathrm{CO}_{2}$ at Sn Cathodes. Electrochim. Acta 2014, 141, 216-225. [CrossRef]

25. Saravanan, K.; Basdogan, Y.; Dean, J.; Keith, J.A. Computational Investigation of $\mathrm{CO}_{2}$ Electroreduction on Tin Oxide and Predictions of Ti, V, Nb and Zr Dopants for Improved Catalysis. J. Mater. Chem. A 2017, 5, 11756-11763. [CrossRef]

26. Medina-Ramos, J.; Pupillo, R.C.; Keane, T.P.; DiMeglio, J.L.; Rosenthal, J. Efficient Conversion of $\mathrm{CO}_{2}$ to $\mathrm{CO}$ Using Tin and Other Inexpensive and Easily Prepared Post-Transition Metal Catalysts. J. Am. Chem. Soc. 2015, 137, 5021-5027. [CrossRef]

27. Zhang, R.; Lv, W.; Lei, L. Role of the Oxide Layer on SN Electrode in Electrochemical Reduction of $\mathrm{CO}_{2}$ to Formate. Appl. Surf. Sci. 2015, 356, 24-29. [CrossRef]

28. Sheng, W.; Kattel, S.; Yao, S.; Yan, B.; Liang, Z.; Hawxhurst, C.J.; Wu, Q.; Chen, J.G. Electrochemical Reduction of $\mathrm{CO}_{2}$ to Synthesis Gas with Controlled CO/ $\mathrm{H}_{2}$ ratios. Energy Environ. Sci. 2017, 10, 1180-1185. [CrossRef]

29. Rumayor, M.; Dominguez-Ramos, A.; Irabien, A. Formic Acid Manufacture: Carbon Dioxide Utilization Alternatives. Appl. Sci. 2018, 8, 914. [CrossRef]

30. Noda, H.; Ikeda, S.; Oda, Y.; Imai, K.; Maeda, M.; Ito, K. Electrochemical Reduction of Carbon Dioxide at Various Metal Electrodes in Aqueous Potassium Hydrogen Carbonate Solution. Bull. Chem. Soc. Jpn. 1990, 63, 2459-2462. [CrossRef]

31. Nakagawa, S.; Kudo, A.; Azuma, M.; Sakata, T. Effect of Pressure on the Electrochemical Reduction of $\mathrm{CO}_{2}$ on Group VIII Metal Electrodes. J. Electroanal. Chem. Interfacial Electrochem. 1991, 308, 339-343. [CrossRef]

32. Yang, D.; Zhu, Q.; Chen, C.; Liu, H.; Liu, Z.; Zhao, Z.; Zhang, X.; Liu, S.; Han, B. Selective Electroreduction of Carbon Dioxide to Methanol on Copper Selenide Nanocatalysts. Nat. Commun. 2019, 10, 1-9. [CrossRef] [PubMed] 